\title{
THE RESPONSIBILITY OF MEMBERSHIP IN THE SASKATCHEWAN NATURAL HISTORY SOCIETY
}

Since my return to Saskatchewan from travelling widely last year in other countries, I have been thinking seriously about the fortunate position enjoyed by Canadians. We are, if we consider our natural resources in relation to our population, the richest people in the world. We have a beautiful and still relatively unspoiled country. But are we sufficiently proud of Canada, and are we facing our responsibility to protect Canadian wonders so that future generations may enjoy them? As editor of the Blue Jay I ask myself how members of the S.N.H.S. can increase their knowledge of the distinctive beauties and values of our natural resources at the same time as they assume a more active responsibility for conservation.

In our magazine we can print educational and thought-provoking articles like those of Dr. E. Peterson on ecological features of our 1966 summer meeting area (pages 102-108) and Dr. L. Murray on Saskatchewan sanctuaries (pages 110-120). We can supply specific information e.g. population changes in the pelican and other colonial birds as reported by Sanderson and by Houston (pages 121-123). In addition to articles and notes published in our quarterly Blue Jay notes, news items and questions can appear in our quarterly Newsletter. We have also a special publication series for longer articles of more permanent value, and we can give financial assistance to the publication of other good natural history contributions.

But we must be prepared to follow up articles such as these with suitable activity. As a society, we can give support to other organizations with similar aims. For example, through the Nature Conservancy of Canada we can aid in the purchase of areas with natural history interest or value in any part of Canada. There are also practical activities in which we can engage individually. For example, do you know any spot or plant or animal in your area which is in special need of protection? If so report it to the Blue Jay or Newsletter so that others may know of the need and be given the opportunity to help in its protection.

By belonging to a local natural history society, many people, in addition to reading and writing, share natural history enthusiasms and problems verbally. Such local societies hold regular monthly meetings featuring films̀ and guest speakers, and have special field trip meetings where members share in the thrills of bird migration or visit areas of natural history interest. We can increase our knowledge and understanding of nature by joining a group. In this connection we are pleased to learn that a local society has recently been organized in Swift Current. Best wishes to members there. Other groups meet in Regina, Saskatoon, Moose Jaw, Prince Albert and in the larger cities of Manitoba and Alberta. If you are within driving distance of any of these cities, you should visit one of the meetings and consider joining the group.

The S.N.H.S. itself has two regular annual meetings. The June meeting is informal and provides opportunity for members of similar interests to get together and exchange knowledge and views. The October meeting is the official business meeting of the society. The treasurer's report is open for inspection, elections are held, resolutions are considered, and discussions of all kinds are held. All members are welcome to attend these two meetings. The next one will be held in the Museum of Natural History in Regina, October 15, 1966. Please come.

Currently, the Society's main project in practical conservation concerns the leasing of land for the prairie dogs. To help meet expenses for this and other possible conservation projects we have a special Sanctuary Fund. When you renew your membership in the Society, consider including a donation for the Sanctuary Fund. Receipts for income tax purposes (page 156) will be issued.

As members of S.N.H.S. we not only show our interest in Natural history in Saskatchewan but also link ourselves with people all over the world who are increasingly aware that we must act now if we hope to save any natural beauties for the future. Be an active member! Help increase our membership. 